ACTA THERIOLOGICA

Vol. 27, 1: 3-24, 1982

\title{
Trophic Impact of Mammals in Terrestrial Ecosystems
}

\author{
Lech RYSZKOWSKI \& Norman R. FRENCH
}

\begin{abstract}
Ryszkowiski L. \& Fench N. R., 1982: Trophic impact of mammals in terrestrial ecosystems. Acta theriol., 27, 1: 3-24 [With 13 Tables].

Mammals are characterized by a wide range of body sizes and highly variable population densities. They are important in energy flow of ecosystems due to the high energetic cost of homeothermy, due to high turn-over rates in populations of small mammals, and due to low efficiency of production. Biomass of mammals is small in comparison to that of soil invertebrates but exceeds above-ground invertebrates in many grasslands, indicating a high contribution to mineralization rates by mammals. Mammals generally consume only a small amount of the vegetation available, but seed consumption may influence plant species composition in forests, and consumption of invertebrates by small mammals may be important in control of these populations. It was found that the impact of carnivores on prey is between that exerted by small mammals on available plants and ungulate impact on plant cover. Complexity of the mammal community varies with type and availability of food resources. The contribution of mammals to total herbivory in grasslands is between $4 \%$ and $38 \%$.

[Dept. of Agrobiology and Forestry, PAS, Swierczewskiego 19, 60-809 Poznań, Poland and Nat. Resource Ecol. Laboratory, Fort Collins, Colorado 80523, USA
\end{abstract}

\section{GENERAL FUNCTIONAL CHARACTERISTICS OF MAMMALS}

Mammals adapt to any terrestrial habitat from arctic to tropics provided they can obtain food. Generally speaking, production of any component per unit time can be defined as the product of mass times turnover. In a functional analysis of an animal community there are three important components of mass. The first is increament of body sizes resulting from physiological, developmental processes of the individual animal. The second component is population biomass resulting from interplay of production processes within the species population. The third is the biomass of the total mammal community resulting from the interplay of various ecosystem processes.

Adult weight of terrestrial mammals in the world varies approximately by a factor of 2.5 million. The range of weight distribution is marked out by shrews (e.g., Suncus etruscus - less than 2 grams) and elephants 
(Loxodonta africana-over five tonnes). But, the weight distribution actually observed within a majority of ecosystems is narrower and ranges from several grams to tons, or a few hundred kilograms.

Energy turnover is speeded up in mammals due to homeothermy. Using an allometric equation for respiration and body weight Fenchel (1974) estimated that homeotherms have 28 times higher respiration rate than poikilotherms of comparable size. On the other hand, when more specific data are compared the differences could be smaller. For example Dawson (1973) estimated that energy required to maintain the same body size in birds and mammals is about 3.5 times higher than for a reptile of equivalent size. These two results could be supplemented by estimates obtained from comparison of other published bioenergetics characteristics of homeotherms and poikilotherms. In spite of variability among comparisons, these comparisons show that energy cost of maintaining homeothermy is much higher than poikilothermy.

Maintainance of a constant body temperature suitable for optimization of various biochemical reactions is advantageous for a high level of activity sustained in extreme or rapidly fluctuating ambient conditions. This requires higher input of energy, but enables colonization of habitats and niches unavailable to poikilotherms. Homeotherms are more independent of ambient conditions than poikilotherms, at the expanse of demaned for more intensive and continuous energy supplies.

Metabolic rate, body temperature, body size and insulative properties are interrelated in homeotherms (Spotila \& Gates, 1975). Small mammals rely to the higher degree on fur insulating properties than large ones, and also make substantial use of burrows, holes, and other shelter places having more suitable microclimatic conditions. These adaptation compensate for need of higher energy input caused by increased metabolic rate due to small body size.

The higher turnover rates in small mammal populations result in speeding up of many individual life processes like growth rate, gestation period, ageing etc. (Bourliere, 1975). The opposite situation is true for large mammals. These different strategies result in bimodal weight distributions in terrestrial mammals which are not observed in swimming or flying homeotherms. Thus many terrestrial mammal species cluster between a few grams to a few kilograms and the second cluster is between a few tens to a few hundreds kilogrames. All size intermediates can be observed between the smallest and the largest birds and the swimming mammals (Bourliere, 1975). Recently it was shown by French, Stoddart \& Bobek (1975) that within small mammal populations one can find two types of strategy for achieving success in exploiting various habitats. The first one is related to high reproduction and rapid growth 
to maturity combined with low survival. The second consists of effective survival with low reproduction. Outbreaks in numbers of small mammals having economic importance were reported mainly for those characterized by the first strategy.

The low efficiency of mammal production is apparent when the ratio of net production to food asimilation of homeotherms and poikilotherms is compared. This ratio varies from 10 per cent to about 40 per cent in many poikilotherms (Golley, 1968; Reichle, 1971) but very rarely reaches the value of 6 per cent in mammals, usually below 2 per cent. Only in domesticated mammal species could efficiencies comparable to some poikilotherms be observed due to selective breeding, special diet, and other factors of modern husbandry.

Herbivory in terrestrial mammals tends to increase with body size. Large canids and felids are exceptions and have very low densities. Many mammal species are omnivorous and take advantage of a variety of plant foods, fungi, invertebrate and vertebrate flesh if available. Thus, omnivory could be considered as a link between primary producers and vertebrate predators of the ecosystem. The direct influence of mammals on energy flow is measured by their consumption which is rather small, except during outbreaks, in the overall picture of ecosystem energetics (see for example Golley, Ryszkowski \& Sokur, 1975; Goszczyński, Ryszkowski \& Truszkowski, 1976). The role of mammals, especially rodents, in mineral cycling is not limited to consumption. Burrowing activity or other forms of matter relocation greatly magnify the role of mammals in mineral cycling beyond the limits set by consumption (Abaturov, 1972; Zlotin \& Khodashova, 1974).

In order to summarize this general discussion on functional characteristic of mammals it should be stressed, that although the energy cost of maintaining the homeothermic way of life is higher than the poikilothermic one, but due to higher turnover of energy various organismal processes as well as biomass production are accelerated and more independent of ambient conditions. In consequence, some ecosystem processes could be magnified, extended into more severe environmental conditions, and proceed during the whole year. In the following parts of this paper more detailed documentation of this statement is presented.

\section{STRUCTURE OF THE TERRESTRIAL MAMMAL COMMUNITY}

Despite many publications on abundance and biomass of particular mammal populations or taxonomic groups there is scanty quantitative information on biomass of the total mammal comunity. Evaluations of mean values taking into account seasonal changes of total mammal com- 
munity supplemented by primary production as well as other animal biomass estimates were obtained only in a few studies on total ecosystem functioning (Satchell, 1971; Zlotin \& Khodashova, 1974; Ryszkowski, 1979; French, 1979). When only live weight was provided by the authors then an approximate factor of 0.33 was used to convert published data into dry weight estimates. It is impossible to estimate the contribution of mammal community biomass to total biomass of animals in all basic types of terrestrial ecosystems because of lack of data. Results of site studies on total animal biomass including Protozoa indicate the share of mammal community is approximatly $4.2 \%$ in deciduous forest in England (Satchell, 1971) and 3.2\% in agroecosystem landscape in Poland (Ryszkowski, 1979). When biomass of Protozoa is neglected then contribution of mammal communities to total biomass of animals vary from $0.1 \%$ to $7.7 \%$ in various ecosystems under study (Table 1). Apart from

\section{Table 1}

Total biomass of animals in forest (Satchell, 1971) and in agroecosystem (Ryszkowski, 1979) mg.d.w $/ \mathrm{m}^{2}$, desert and grassland's (French 1979).

\begin{tabular}{|c|c|c|c|c|c|c|}
\hline Soil & Forest ${ }^{1}$ & $\begin{array}{c}\text { Agro- } \\
\text { ecosystem } 1\end{array}$ & Desert & $\begin{array}{l}\text { Short- } \\
\text { grass }\end{array}$ & Mixed & $\begin{array}{l}\text { Tall- } \\
\text { grass }\end{array}$ \\
\hline Nematoda & 200 & 260 & 30 & 430 & 1323 & 398 \\
\hline Annelida & 1600 & 2200 & 0 & 0 & 0 & - \\
\hline Arthropoda & 1200 & 173 & 756 & 549 & 787 & 384 \\
\hline Mollusca & 500 & 0 & 0 & 0 & 0 & 0 \\
\hline Total soil invertebrates & 3500 & 2633 & 786 & 979 & 2110 & 782 \\
\hline Above-ground invertebrates & 100 & 133 & 52 & 32 & 372 & 166 \\
\hline Amphibia & - & 0.6 & - & - & - & - \\
\hline Reptiles & - & - & 32 & 2.5 & - & 一 \\
\hline Birds & - & 15 & 1 & 7.5 & 4 & 4.7 \\
\hline Mammals & 165 & 193 & 14 & 40 & 3 & 80 \\
\hline Total vertebrates & & 208.6 & 47 & 50 & 7 & 85 \\
\hline Total animals & 3765 & 2974.6 & 885 & 1061 & 2489 & 1033 \\
\hline Percentage of mammals & 4.4 & 6.5 & 1.6 & 3.8 & 0.1 & 7.7 \\
\hline
\end{tabular}

1 In orginal papers data on Protozoa biomass are shown.

the scanty information it can be assumed in regard with general ecological knowledge that the share of total mammal biomass does not exceed a couple per cent in other types ecosystems. Thus, for example, Chernov, Khodashova \& Zlotin (1967) compiling many partial studies assumed the share of vertebrate biomass in total animal biomass to be equal to $0.12 \%$ in temperate deciduous forest, about $1 \%$ in steppe, from $1.6 \%$ to $4 \%$ in mixed forest and taiga and up $5 \%$ tundra.

In total 24 estimates of the total mammal community biomass were found (Table 2). Most results concern the north temperate regions. Tropical and arctic habitats are not represented practically. The lowest 
Table 2

Biomass of total mammal community in various terrestrial ecosystems (mg.d.w./m²)

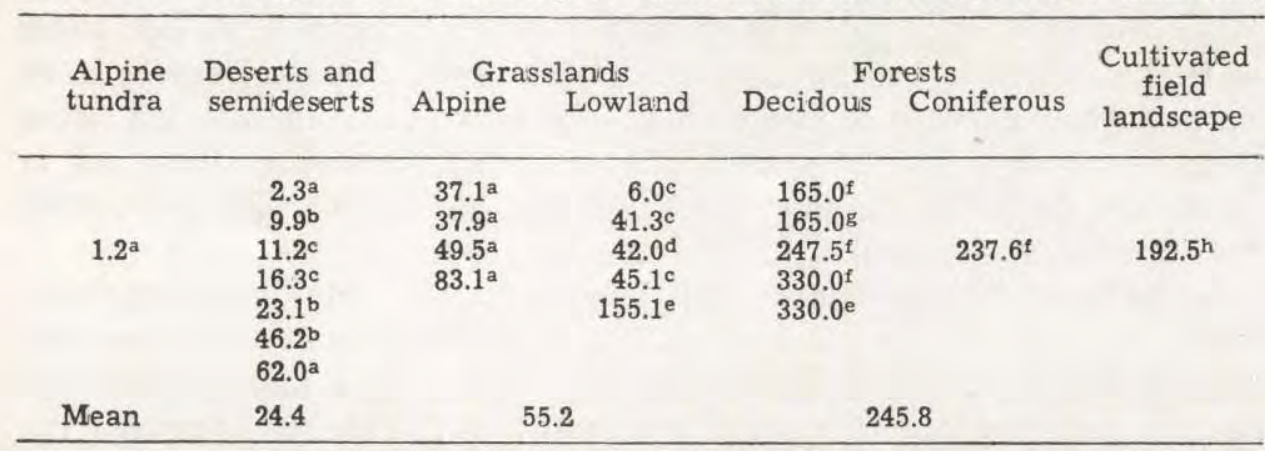

References: a Zlotin (1975) Tian-Shan, Asia, bRodin (1977) Karakum, Asia, cFrench (1979) North America, 'Lamotte (1975) North Africa, eZlotin \& Khodashova (1974) Eastern Europe, ${ }^{1}$ Turček (1971) Central Europe, ${ }^{g}$ Satchell (1971) Western Europe, hRyszkowski (1979) Central Europe

biomass of mammal community was recorded in alpine tundra: $1.2 \mathrm{mg}$ d. $\mathrm{w} / \mathrm{m}^{2}$, and in alpine desert: $2.3 \mathrm{mg} \mathrm{d}$. $\mathrm{w} / \mathrm{m}^{2}$ by Zlotin (1975) in TianShan mountains. In both situations small mammals (voles and marmots) constituted almost the total community ( 86 and $91 \%$ respectively).

Calculating mean values for desert, grasslands and forests one can find that the mammal biomass in forests is on the average ten times higher that in deserts.

Forest mammal biomass is about 3.5 time higher than grassland. Variability of the total biomass is high in analysed ecosystems. The same is true with major components of the mammal community such as small mammals, lagomorphs (intermediate size class), ungulates, carnivores. Biomass of each component fluctuates greatly, showing even higher variability than biomass of the total mammal community (Table 3 ).

Table 3

Biamass structure of mammal community at desert, grassland and agroecosystem sites (mg.d.w. $/ \mathrm{m}^{2}$ ).

\begin{tabular}{lccccr}
\hline \multicolumn{1}{c}{ Site } & $\begin{array}{c}\text { Small } \\
\text { mammals }\end{array}$ & Lagomorphs & $\begin{array}{c}\text { Ungulates } \\
\text { (wild) }\end{array}$ & Carnivores & Total \\
\hline Mojave deserta & 10.16 & 0.01 & 0 & 1.0 & 11.17 \\
Desert grasslanda $^{\text {Southern shortgrass }}{ }^{\mathrm{a}}$ & 9.79 & 0.94 & 5.5 & 0.11 & 16.34 \\
Northern shortgrass $^{\mathrm{a}}$ & 4.96 & 0.90 & 0 & 0.13 & 5.99 \\
Mixeda $^{\text {Tallgrass }}$ & 9.35 & 32.50 & 3.24 & 0.09 & 45.18 \\
Agroecosystem $^{\mathrm{b}}$ & 2.18 & 0.53 & $824.27^{1}$ & 0.08 & 827.06 \\
\hline
\end{tabular}

1 Unusually high at this location due to river near site, ${ }^{2}$ High insectivores especially mole (12 mg) populations, aFrench (1979), bRyszkowski (1979). 
It seems that ungulate biomass could attain high levels if predator control is limited and food resources are abundant as in reserves or other protected areas. Thus, comparing ungulate biomass in various zones of USSR Dobrinsky (1975) has shown, that on the average from 10 to 20 times higher biomass is observed in protected than unprotected areas (Table 4). Biomass of large mammals recorded for savanna reserves in Africa are the highest published to date (Bourliere, 1965; Lamprey, 1964; Petrides \& Swank, 1965).

Large body sizes coupland with lower turnover rates of energy correlate with slower rate of various life processes like reproduction and growth in comparison to small mammals. Thus, ungulate populations do not fluctuate rapidly like small mammals, and probably approach the food-limiting conditions more consistently than small mammals. It is well known, that in the case of insufficient impact of predators, ungulate populations build up in numbers to the level of vegetation damage (e. $g$. Mohler at al., 1951).

The highest ungulate biomass recorded for unprotected areas by Dobrinsky (1975) was in forests (Table 4) indicating better shelter conditions than in other ecosystems, especially against hunting pressure of man. In protected areas Dobrinsky (1975) recorded the highest ungulate biomass in grasslands (Table 4). Average values of total mammal population biomass evaluated in this paper in three types of ecosystems are lower than values presented by Khodashova (1966) obtained by compilation of seperate population studies (Table 4).

In terrestrial ecosystems animal biomass is concentrated in soil invertebrates. Above-ground animal biomass is usually in the order of a few percent of the total. But, considering only the above-ground invertebrates one may find in some grassland ecosystems that total mammal biomass exceeds above-ground invertebrate biomass (Table 5 ). In these situations enormous number of invertebrate species, especially insects, is balanced by a few species of mammals. The higher biomass of mammals than inertebrates above-ground means that much more covalent bind energy stored in consumer tissue is converted to thermal energy because of higher energy cost in maintaining homeothermy. In other words it means the higher contribution of mammals to aboveground fauna means higher mineralization rate of animal biomass in some grassland ecosystems.

\section{CONSUMPTION BY THE MAMMALS}

Grassland ecosystems are controlled to a higher degree by climatic factors, especially water, in the sequence of dry and wet seasons, and 


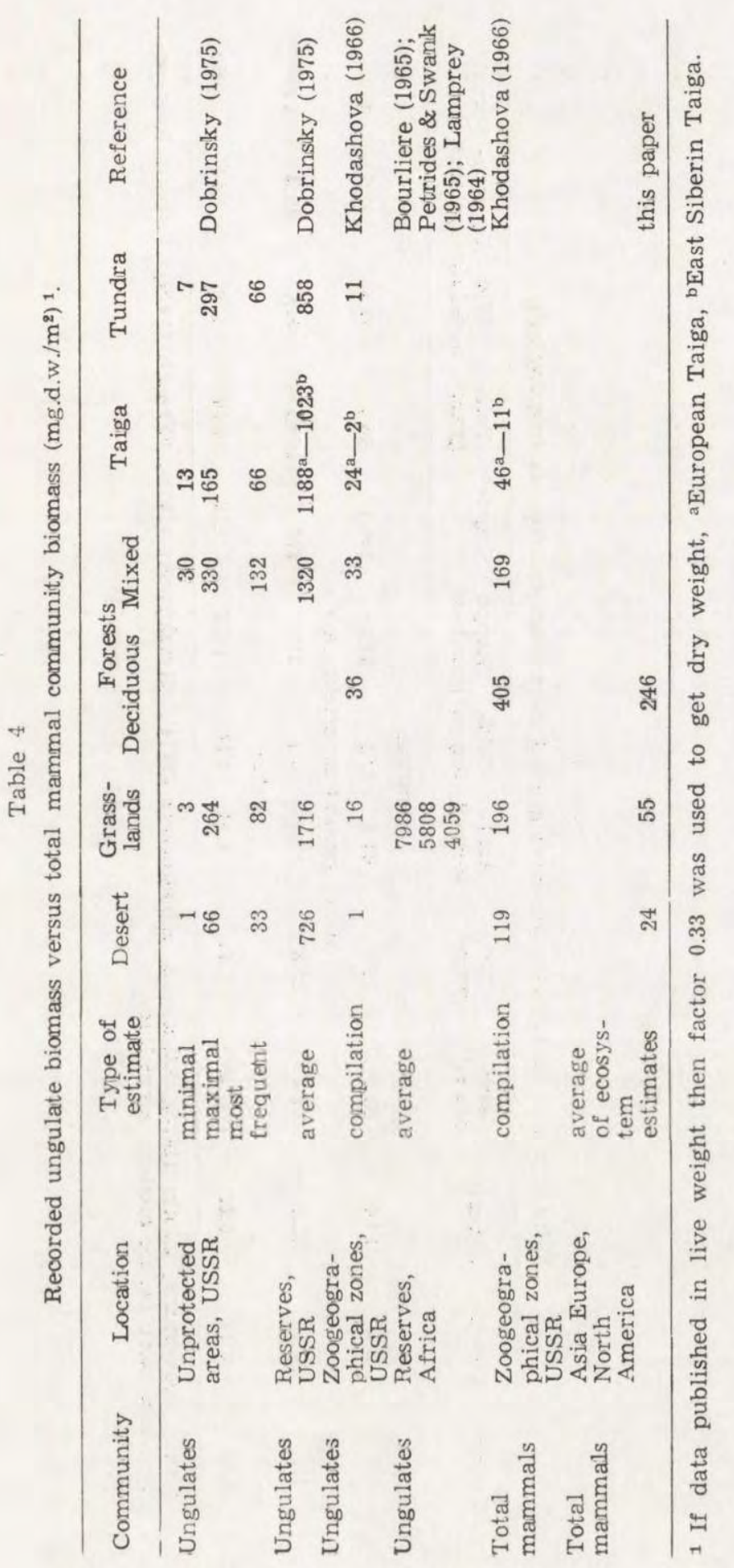




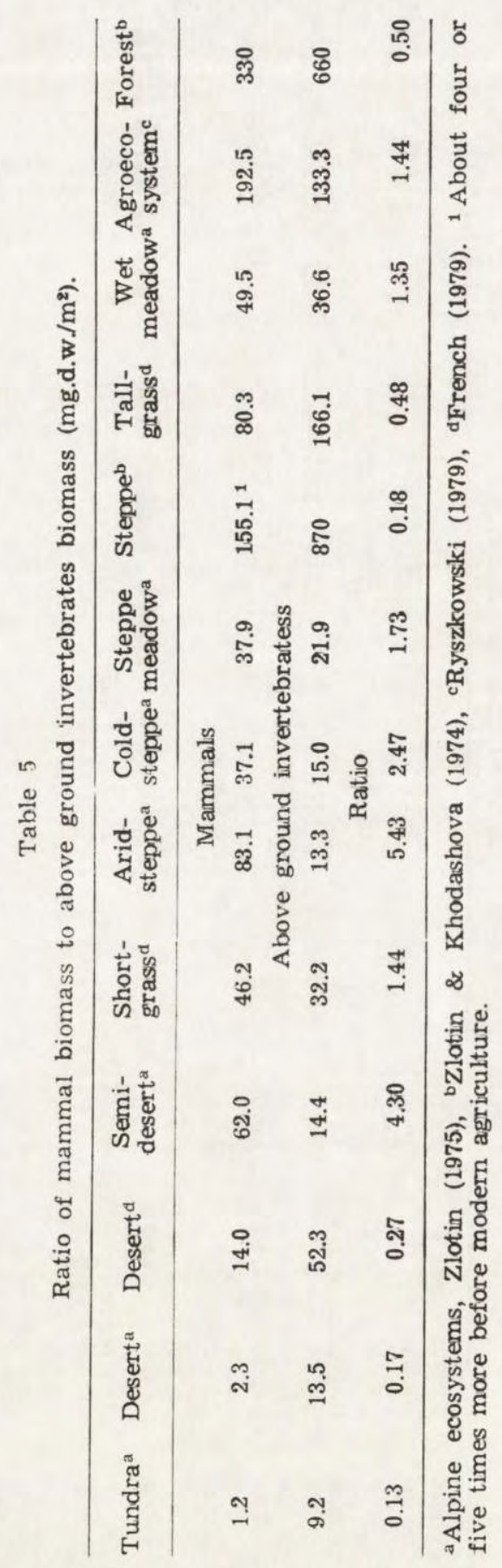


practically all above-ground plant biomass becomes dry or dead and is shed when growing season ends. Thus, consumption of even a large quantity of above-ground vegetation could be accomplished without damage to plant cover, especially because grazing promotes regrowth processes in plants. In forests, where a substantial part of annual aboveground primary production is accumulated in live standing biomass, the amount of vegetation consumed by herbivores could more easily impair photosynthetic capacities of trees.

The data gathered from a variety of ecosystems through the International Biological Programme indicate that usually a very low proportion of herbage is consumed by small mammals (Table 6; Golley,

Table 6

Yearly energy consumption of small mammals as the percentage of available primary production.

\begin{tabular}{|c|c|c|}
\hline Ecosystem & Consumption, $\%$ & Reference \\
\hline \multicolumn{3}{|l|}{ Agricultural fields } \\
\hline Rye & 0.5 & Trojan (1969) \\
\hline Alfalfa & 0.8 & Trojan (1969) \\
\hline Alfalfa & $1.4-21.4$ & Ryszkowski et al. (1973) \\
\hline \multicolumn{3}{|l|}{ Forest plantations } \\
\hline Spruce & $1.8-3.1$ & Hansson (1971) \\
\hline Mixed & 3.1 & Gębczyńska (1970) \\
\hline \multicolumn{3}{|l|}{ Coniferous forests } \\
\hline $\begin{array}{l}\text { Pine-lichen dry forest } \\
\text { Pine-blueberry }\end{array}$ & 1.9 & Ryszkowski (1969) \\
\hline $\begin{array}{l}\text { Pine-blueberry } \\
\text { (40 years) }\end{array}$ & $0.9-1.2$ & Ryszkowski (1969) \\
\hline $\begin{array}{l}\text { Pine-blueberry } \\
(140 \text { years })\end{array}$ & & \\
\hline Pine-oak & $0.6-0.8$ & Ryszkowski (1969) \\
\hline Taiga (Alaska) & 13.5 & Grodziński (1971) \\
\hline \multicolumn{3}{|l|}{ Deciduous forests } \\
\hline Oak-hornbeam & 4.6 & Grodziński (1971) \\
\hline Beach forest & $2.4-6.7$ & Grodziński et al. (1969) \\
\hline Alder-ash & 2.2 & Aulak (1973) \\
\hline Mixed forest & 0.6 & Ryszkowski (1969) \\
\hline \multicolumn{3}{|l|}{ Grasslands } \\
\hline Grass field & 1.3 & Trojan (1969) \\
\hline Grass field & 1.6 & Golley (1960) \\
\hline Desert shrub & 5.5 & Chew \& Chew (1970) \\
\hline
\end{tabular}

Ryszkowski \& Sokur, 1975). The vegetation is seriously damaged by small mammals only in the case of population outbreak. It seems that quite the contrary situation exists in large herbivorous mammals. The ratio of food consumed to food available is usually much higher than in the case of small mammals (Table 7). These results of studies support the conclusion that ungulates approach the food limiting conditions more consistently than small mammals. One may expect therefore, that the 
impact of ungulates on vegetative parts of plants could be substantial, especially when density of predators is limited.

The opposite situation is expected with small mammals in forests. Selection of seeds for food by rodents has a greater influence on the species composition of plant cover in forest ecosystems where seeds play an important role in propagation of vegetation than in grasslands where much of the regrowth is from roots (Dinesman, 1961; Golley, Ryszkowski \& Sokur, 1975).

Table 7

Percentage of available energy utilized by large mammals.

\begin{tabular}{|c|c|c|c|c|}
\hline Location & Species & Period & $\begin{array}{l}\text { Percentage } \\
\text { consumed }\end{array}$ & Source \\
\hline \multirow{5}{*}{$\begin{array}{l}\text { Grassland, } \\
\text { Uganda } \\
\text { Grassland, } \\
\text { Uganda } \\
\text { Grassland, } \\
\text { Tanganika } \\
\text { Deciduous } \\
\text { forest, } \\
\text { Poland }\end{array}$} & $\begin{array}{l}\text { Adenota } \\
\text { kob thomasi }\end{array}$ & whole year & 10 & Buechner \& Golley (1967) \\
\hline & $\begin{array}{l}\text { Loxodonta } \\
\text { africana }\end{array}$ & whole year & 9.5 & Petrides et al. (1968) \\
\hline & Ungulates & whole year & 28 & $\begin{array}{l}\text { Wiegert \& Evans (1967) } \\
\text { acc. to Lamprey data }\end{array}$ \\
\hline & C. capreolus & whole year & 8.4 & Bobek et al. (1972) \\
\hline & C. elaphus & winter & 15.7 & \\
\hline $\begin{array}{l}\text { Deciduous } \\
\text { forest, } \\
\text { Poland }\end{array}$ & as above & $\begin{array}{l}\text { growing season } \\
\text { winter }\end{array}$ & $\begin{array}{l}19.1 \\
25.5\end{array}$ & Bobek et al. (1975) \\
\hline $\begin{array}{l}\text { Deciduous } \\
\text { forest, } \\
\text { Poland }\end{array}$ & as above & $\begin{array}{l}\text { growing season } \\
\text { winter }\end{array}$ & $\begin{array}{r}7.3 \\
15.5\end{array}$ & \\
\hline $\begin{array}{l}\text { Coniferous } \\
\text { forest, } \\
\text { Poland }\end{array}$ & as above & $\begin{array}{l}\text { growing season } \\
\text { winter }\end{array}$ & $\begin{array}{r}4.0 \\
12.0\end{array}$ & \\
\hline $\begin{array}{l}\text { Deciduous } \\
\text { forest, } \\
\text { Poland }\end{array}$ & Ungulates & whole year & 5.0 & $\begin{array}{l}\text { Borowski \& Dzięciołowski } \\
(1980)\end{array}$ \\
\hline
\end{tabular}

Analysis of the impact of predators on prey in various homeotherm populations indicates that the ratios of biomass consumed to available prey (Table 8 ) are between those indices observed in small mammals (Table 6) and in ungulate populations (Table 7).

More detailed studies on food habits, diets and bioenergetics have shown that many so called herbivorous species of small mammals actually take advantage of a variety of plant foods as well as insects, other invertebrates, fungi and even vertebrate flesh if available. Most small mammals are omnivorous. In studies on small mammals in various grassland ecosystems in North America carried out within the IBP it was shown that in some arid grasslands carnivory is nearly as important as herbivory (Table 9). Analyses of food utilization indicate that the small mammal impact on herbage food is much smaller than on animal 
food (Table 10, French at al. 1976). Only in one case nearly $20 \%$ of available herbage food was consumed. This occurred during a year of low primary production at the desert site. Annual plants in deserts do not germinate in years of unfavorable growing conditions. Thus, the failure of seed production may have forced high utilization of herbage

Table 8

Predator impact on prey populations.

\begin{tabular}{|c|c|c|c|}
\hline Predators & Prey & $\begin{array}{c}\text { Pressure } \\
\text { on prey, } \%\end{array}$ & Reference \\
\hline Lion & antelope gnu & $2.2-3.3$ & Schaller (1972) \\
\hline Lion & antelope gnu & 1.2 & Kruuk \& Turner (1967) \\
\hline Hyena & antelope gnu & $1.7-2.7$ & Schaller (1972) \\
\hline Hyena & antelope gnu & $1.6-2.6$ & Kruuk (1970) \\
\hline Hyena & zebra & $1.7-2.3$ & Kruuk (1970) \\
\hline Hyena & $\begin{array}{l}\text { Thompson's } \\
\text { gazella }\end{array}$ & $2.2-6.5$ & Kruuk (1970) \\
\hline Hyena & zebra & $3.2-4.2$ & Schaller (1972) \\
\hline Wolf & white-tailed deer & 10.0 & Kolenosky (1972) \\
\hline Lynx & snowshoe hare & $2.1-6.4$ & Nellis et al. (1972) \\
\hline Lynx & red squirrel & $1.1-1.6$ & Nellis et al. (1972) \\
\hline Fox & European hare & 11.0 & Pielowski et al. (1974) \\
\hline Big predators & ungulates & $9.0-10.0$ & Schaller (1972) \\
\hline $\begin{array}{l}\text { Big predators } \\
\text { Total set of }\end{array}$ & ungulates & 15.5 & Foster \& Coe (1968) \\
\hline $\begin{array}{l}\text { homeotherm } \\
\text { predators } \\
\text { Total set of }\end{array}$ & forest rodents & $18.2-55.8$ & Ryszkowski et al. (1973) \\
\hline $\begin{array}{l}\text { homeotherm } \\
\text { predators }\end{array}$ & common vole & $9.4-47.4$ & Ryszkowski et al. (1973) \\
\hline
\end{tabular}

Table 9

Sources of energy utilized by small mammal populations at various grassland sites (French et al., 1976)

\begin{tabular}{lccc}
\hline \multicolumn{1}{c}{ Site } & $\begin{array}{c}\text { Biomass, mg d.w./m² } \\
\text { (avg. for } 3 \text { years) }\end{array}$ & Carnivore, $\%$ & Herbivore, $\%$ \\
\hline Tallgrass & 33.20 & 13 & 87 \\
Midgrass & 2.18 & 53 & 47 \\
Northern shortgrass & 9.35 & 52 & 48 \\
Southern shortgrass & 4.96 & 60 & 40 \\
Desert grassland & 9.79 & 45 & 55 \\
Mojave desert & 10.16 & 10 & $90^{1}$ \\
\hline
\end{tabular}

1 Includes $45 \%$ granivory.

by small mammals. In desert environments rapid decrease of primary production efficiency could create conditions similar to population outbreak situations even at low mammal population density. French et al. (1976) estimate that small mammal presures on invertebrate components of above-ground animal community were very high at nearly all 
sites (Table 10). The one exception was the site with very low small mammal density.

One of the most interesting points emerging from these studies is that estimated impact of small mammals on the epigeic invertebrates is usually much higher than impact of mammal predators on their mammal food resources (compare table 10 and 8). Only the impact of the total set of predators including six mammal predator species and five species of predatory birds, in agricultural landscape approachs the level of pressure exerted by small mammals on epigeic invertebrates in some grassland ecosystems. Thus, the small mammal community may be an important factor in control of above-ground invertebrates.

Table 10

Fraction of available energy utulized by small mammal communities at various grassland sites (after French et al., 1976).

\begin{tabular}{lccc}
\hline Grassland sites & Year & Herbage & Animal \\
Tallgrass & 1970 & 0.063 & 0.88 \\
& 1971 & 0.010 & 0.38 \\
Midgrass & 1972 & 0.047 & all ? \\
& 1970 & 0.002 & 0.08 \\
Northern & 1971 & 0.001 & 0.08 \\
Shortgrass & 1972 & 0.002 & 0.02 \\
& 1970 & - & all ? \\
Southern & 1971 & - & 0.42 \\
Shortgrass & 1972 & 0.005 & 0.83 \\
Desert grassland & 1970 & - & 0.96 \\
& 1971 & 0.013 & 0.61 \\
& 1972 & 0.091 & 0.11 \\
& 1970 & 0.032 & all ? \\
& 1971 & 0.190 & all ? \\
\hline
\end{tabular}

It seems that the granivores predominate in desert ecosystems where they also exert the highest recorded impact on seed numbers (Table 11). Because of high impact evoked by small mammals both on seeds and above-ground invertebrates one may conclude that the abundance of these resources is coupled with small mammal populations at least in some ecosystems. Thus, for example the selection of seeds for food by rodents has substantial influence on the species composition of seedlings in deciduous forest and thus on the composition of forest regrowth (Dinesman, 1961). The following general trophic description of small mammals is based on French et al. (1975). The structurally simple habitats have small mammal populations dominated by herbivores, while with increasing degrees of structural complexity the predominant roles are displayed by omnivores, then granivores, and finally carnivores. Tundra habitats may have one to several herbivorous species of micro- 
tines, a single omnivore and a single carnivore (Batzli, 1975). The grassland ecosystem generally has a single species of herbivorus small mammal, two to three species of omnivores, none or a single species of granivore, and one carnivore (French et al., 1976). The temperate deciduous forests the small mammals play a very minor role on the forest floor, and may be characterized by a single species each of herbivore, of granivore and of omnivore. Deserts are dominated by granivorous species of small mammals, with perhaps one omnivore and one carnivore, and on occasion an herbivore in addition. Tropical ecosystems, with their many species of small mammals, may have one or two each of herbivore, granivore and omnivore, and generally several

Table 11

Percentage of available seeds cansumed by small mammals.

\begin{tabular}{|c|c|c|}
\hline Ecosystem & Consumption, $\%$ & Reference \\
\hline Old field & 12 & Odum et al. (1962) \\
\hline Savanina & 9 & Poulet (1972) \\
\hline Desert & 95 & Soholt (1973) \\
\hline Desert & 85 & $\begin{array}{l}\text { Chew \& Chew } \\
\text { (1970) }\end{array}$ \\
\hline Bunchgrass & & \\
\hline Sitanion hystrix & $1-8$ & $\begin{array}{l}\text { Becker \& Balph } \\
(1976)\end{array}$ \\
\hline Atriplex confertifolius & $4-32$ & $\begin{array}{l}\text { Becker \& Balph } \\
(1976)\end{array}$ \\
\hline Tallgrass & 8 & $\begin{array}{l}\text { French et al. } \\
\text { (1976) }\end{array}$ \\
\hline Northern shortgrass & 0.2 & $\begin{array}{l}\text { French et al. } \\
\text { (1976) }\end{array}$ \\
\hline
\end{tabular}

species that may be partially carnivore and partially scavenger (Fleming, 1975). This is not including the large segment of the tropical small mammal community feeding on insects, the bats (Fleming 1973).

In comparatively simple ecosystems the energy coupling between the small mammals and the producers must be short and direct. For this reason the herbivores dominate in arctic and alpine environments. The high degree of direct dependence upon the resource base has resulted in populations than can rapidly exploit given resources when they become available, fluctuate widely in numbers during a short span of time, in other words, the $r$-selected species. In the more variable environment of grassland, omnivores predominate perhaps because they are capable of switching as resource conditions change. In temperate deciduous forests small mammals have little impact on system energetics, although they may control species composition of forest regrowth. In the desert, on the other hand, there is a fairly reliable source of energy in the form of seeds which are abundantly exploited by granivores. Labile 
metabolic characteristics of some of the desert dwelling forms enables them to persist during infrequent periods of unusual scarcity of seed resources. In tropics the carnivore-omnivore category predominates, exploiting the abundant invertebrate and small vertebrate consumers that occur in the system. In the less seasonal environment resources are more constant and there is little need for adaptation toward rapid exploitation of periodically available resources.

With increasing size of mammals herbivory is spread among more mammalian species. Larger herbivorous species have higher impact on vegetative parts of plant cover (browse, grasses) than small mammals. Selective grazing by ungulates is an important determinant of species composition of plant cover especially in grasslands (e.g. Clements \& Shelford, 1939). Their importance for ecosystem succession was recognized long ago by many pioneers of ecology.

In an attempt to evaluate the importance of different consumer groups in grassland ecosystems French (1980) evaluated consumption of basic functional groups of animals in four grassland ecosystems. Data models, involving use of computer models with field data as input were used on animal groups under question, to obtain estimates of consumption at shortgrass, mixed-grass, tallgrass, and desert grassland sites. Field data included basic microclimatic characteristics and estimates of animal and plant species biomass and densities. The data models use respiration equations, growth equations, assimilation rates, and diet preferences, which are specific to each taxon, to determine consumption. Aboveground animal consumption is only about $3-8 \%$ of the total consumption (Table 12 ). Only $2-7 \%$ of primary production is consumed above-ground, but below-ground $7-26 \%$ is consumed. Predators consume most of the production of primary consumers, however. Total consumption increase from the shortgrass to the tallgrass sites, and above-ground consumption becomes slightly greater. As primary production above-ground becomes greater between sites, consumers eat a greater proportion of this production, indicating a density - dependent mechanisms of control of plant growth. Plant tissue feeders are more important than plant sap feeders above-ground but the reverse is true below-ground. There may, therefore, be less damage to under-ground parts by consumers. Mammal contribution to the total above-ground consumption varies from $4 \%$ (mixed grassland) to as high as $38 \%$ at tallgrass site. Although the amount of energy consumed depends mainly on the level of biomass standing crop of animals in question, nevertheless homeothermy magnifies the consumption compared to poikilothermy. The contribution of mammal consumption among secondary consumers varied from $4.2 \%$ (mixed) to $42.9 \%$ at shortgrass site. Thus, in three out of four analysed grassland 
ecosystems mammals are very important components of energy flow at higher trophic levels in the above-ground segment of ecosystems.

These results support the conclusion that mammals may play important roles in elaboration of trophic structure of above-ground segment of ecosystems. The effects of consumption processes may be considered as mechanisms of supplying organic matter to the soil, through spreading over the whole year the fall of clipped but not consumed plant material

Table 12

Consumption (kcal.m $\mathrm{m}^{-2}$ season $^{-1}$ ) by consumers at four grassland sites (after French, 1979).

\begin{tabular}{|c|c|c|c|c|}
\hline Consumers & $\begin{array}{c}\text { Desert } \\
\text { grassland }\end{array}$ & $\begin{array}{l}\text { Short- } \\
\text { grass }\end{array}$ & Mixed & $\begin{array}{l}\text { Tall- } \\
\text { grass }\end{array}$ \\
\hline \multicolumn{5}{|l|}{ ABOVE-GROUND } \\
\hline \multicolumn{5}{|l|}{ Primary consumers } \\
\hline \multicolumn{5}{|l|}{ Plant tissue feeders } \\
\hline Mammals & 1.69 & 0.51 & 1.60 & 20.90 \\
\hline Arthropods & 8.12 & 3.54 & 6.33 & 6.91 \\
\hline Plant sap feeding arthropods & 2.18 & 2.98 & 24.72 & 12.60 \\
\hline Pollen nectar feeding arthropods & 0.55 & 0.59 & 0.98 & 6.66 \\
\hline \multicolumn{5}{|l|}{ Seed feeders } \\
\hline Birds & 6.51 & 0.62 & 0.16 & 0.59 \\
\hline Mammals & 0.70 & 0.08 & 0.20 & 11.28 \\
\hline Arthropods & 1.73 & 0.12 & 0.17 & 1.34 \\
\hline Dead plant-litter feeding arthropods & 12.36 & 1.55 & 9.88 & 24.35 \\
\hline \multicolumn{5}{|l|}{ Secondary consumers } \\
\hline \multicolumn{5}{|l|}{ Predators } \\
\hline Birds & 3.98 & 1.13 & 0.88 & 1.65 \\
\hline Mammals & 1.49 & 1.28 & 0.20 & 2.48 \\
\hline Arthropods & 2.30 & 0.55 & 3.25 & 6.43 \\
\hline Scavenger arthropods & 0.51 & 0.02 & 0.34 & 0.47 \\
\hline \multicolumn{5}{|l|}{ BELOW-GROUND INVERTEBRATES } \\
\hline \multicolumn{5}{|l|}{ Primary consumers } \\
\hline Plant tissue feeders & - & 40.22 & 244.26 & 69.02 \\
\hline Plant sap feeders & - & 192.93 & 382.38 & 369.64 \\
\hline Fungal feeders & - & 97.60 & 33.66 & 215.47 \\
\hline Bacteria feeders & - & 101.13 & 66.53 & 83.91 \\
\hline \multicolumn{5}{|l|}{ Secondary consumers } \\
\hline Predators & - & 28.46 & 117.83 & 78.02 \\
\hline Protozoa feeders & - & 11.67 & 31.65 & 22.36 \\
\hline
\end{tabular}

and by addition of unassimilated food. There are accumulating data indicating that mammals may speed up decomposition processes in ecosystems (e.g. Zlotin \& Khodashova, 1974). While the quantity of nitrogen entering the top soil from decomposition of litter produced by mammals is significant only with very high densities, the clipping rate, about which we have little information, may be substantially higher than usually assumed. This would suggest that herbivorous mammals may also serve as regulators of the supply of fresh organic matter made available for decomposition. There is some information that green plant material, such as enters the litter via mammal clipping and mammal

2 - Acta Theriologica 
feces decomposes more rapidly than does brown, dry plant material entering the litter from standing dead plants. Thus, mammals are capable of affecting decomposition by altering both the quantity and quality of litter.

\section{EVALUATION OF THE MAMMAL'S ROLE IN TERRESTRIAL ECOSYSTEMS}

Much of the above information on the trophic relationships was obtained during recent studies on energy flow in ecosystems accomplished by the International Biological Programme. These studies have revelated the intriguing pattern of direct impact of mammals on primary producers as well as on other consumers. Thus, for example, small mammals may play an important role in seed elimination or display serious impact on above-ground invertebrates in some ecosystems. Ungulates may control plant species composition. Mammals accelerate decomposition processes of plant materials. All these impacts of mammals are related to their direct role in energy flow in ecosystems, which is relatively small in comparison to the invertebrate contribution, to say nothing about microbes. Thus, the magnifing effects of homeothermy on energy flow does not surpass the effect of lower density and longer turnover times characteristic of mammals, in comparison to invertebrates. There are suggestions that the role of mammals is mainly expressed in their rate control of several fundamental processes for ecosystem functioning. For example, it has been convincingly argued from a theoretical standpoint that consumers in general, and mammals in particular, fulfill the requirements for regulators of the producer, decomposer system (Golley, 1973; Golley, Ryszkowski \& Sokur, 1975). These impacts can be grouped into four main categories related to the following effects of mammals: a) destruction of a component; b) movement of materials or components: c) alteration of the environment, and d) interactions with other consumers. All these effects are not strictly related to magnitude of energy flow and therefore could play the role of feedback mechanisms for the plant-decomposer system.

Thus for example the burrowing activity of small mammals may be the important agent supplying nutrients for plants across the soil profile. This nutrient transfer could be especially important in dry climatic conditions when capillary ascension of ground water does not operate as in dry grassland ecosystems. An increase in small mammal density or in proportion of burrowers results in an increase in rate of nutrient cycling in the ecosystem. When nutrients are tied up in undecomposed organic matter small mammals may influence primary production by dispossing from deep layers new supplies of minerals (Golley, Ryszkow- 
ski \& Sokur, 1975). Mammals, by changing the relief of ground, influence water runoff, which influences local moisture conditions in soil and may also influence growth of plants. In the case of many plant species mammal grazing has a direct stimulating effect on regrowth processes. Such examples of positive or negative feedback impact of consumers on primary producers or decomposers could be expanded. However, in spite of abundant qualitative information there is very poor quantitative understanding of these feedback effects. This lack of knowledge applies to actions of the mammals and also to the quantitative response of the vegetation or decomposers to these actions. Thus, the knowledge of mammal impact based on processes not strictly related to energy flow is very limited. However, there are published contributions based on meager information. Thus, for example, evaluating the role of small mammals in temperate ecosystems suggested that their highest impact

Table 13

Increase of mammal production due to energy subsidies provided by husbandry.

\begin{tabular}{|c|c|c|c|}
\hline Species & Location & $\begin{array}{l}\text { Net production } \\
\left.\text { (kcal.m-2 year }{ }^{-1}\right)\end{array}$ & Reference \\
\hline $\begin{array}{l}44 \text { small mammal } \\
\text { populations }\end{array}$ & $\begin{array}{l}\text { various natural } \\
\text { habitats }\end{array}$ & up to 0.600 & French et al. (1976) \\
\hline Alces americana & Michigan, USA & 0.200 & Jordan et al. (1971) \\
\hline $\begin{array}{l}\text { Cervus elaphus } \\
\text { Capreolus } \\
\text { capreolus }\end{array}$ & Poland & 0.300 & Bobek (1974) \\
\hline $\begin{array}{l}\text { Loxodonta } \\
\text { africana }\end{array}$ & Uganda & 0.340 & Petrides et al. (1968) \\
\hline $\begin{array}{l}\text { Adenota kob } \\
\text { thomasi }\end{array}$ & Uganda & 0.807 & $\begin{array}{l}\text { Buechner \& Golley } \\
\text { (1967) }\end{array}$ \\
\hline Masai cattle & Tanzania & 2.650 & Deans et al. (1968) \\
\hline Beef cattle & $\begin{array}{l}\text { average for } \\
\text { western USA } \\
\text { native range }\end{array}$ & 6.500 & Cook (1971) \\
\hline Beef cattle & improved range, USA & 140.000 & Hull et al. (1971) \\
\hline
\end{tabular}

is in temperate grassland ecosystems (Golley, Ryszkowski \& Sokur, 1975). Under very intensive agriculture small mammals are practically eliminated and, at the other extreme, in mature forest the impact of small mammals on the system is negligible.

The importance of mammals to man is far greater than their relative importance to ecosystem function, because of their available protein, their capacity to attain high densities with resulting damage to agricultural stores, and their ability to serve as reservoirs of disease that affect man. Through specific interactions in the utilization of ecosystems by man conflict with mammals intensifies relationship to structure and 
function of ecosystems. These results are obtained by energy subsidies which permit attainment of needed goals. In the case of modern husbandry the results obtained are striking (Table 13).

Consideration of the different types of energy utilization among consumer groups begins to clarify the means and mechanisms of comparative system impact. Mammals display an important role in control of transfer rates of energy and matter in ecosystems like other consumers. Their specific characteristics are related to homeothermy which make them more independent of ambient conditions. Therefore their actions are comparatively less related to the magnitude of energy flow than the effects of invertebrate actions.

\section{REFERENCES}

1. Abaturov B. D., 1972: The role of burrowing animals in the transport of mineral substances in the soil. Pedobiologia, 12: 261-266.

2. Aulak W., 1973: Production and energy requirements in a population of the bank vole in a deciduous forest of Circaeo-Alnetum type. Acta theriol., 18: $167-190$.

3. Batzli G. O., 1975: The role of small mammals in arctic ecosystems [In "Small mammals: their productivity and population dynamics", Eds. F. B. Golley, K. Petrusewicz, L. Ryszkowski]. Cambridge Univ. Press.: 243-268. London.

4. Becker E. L. \& Balph D. F., 1976: Plant food preferences of two sympatric rodents and their potential impact on a great basin shrub community. Desert Biome USIBP. Report of 1975 progress. Vol. 3. Process studies. Vertebrate Section, Utah State Univ.: 26-36. Logan.

5. Bobek B., 1974: Production and standing crop of deer populations in a deciduous forest. First Intern. Theriol. Congr., Transactions., Nauka: 76 Moskow.

6. Bobek B., Weiner J. \& Zieliński J., 1972: Food supply and its consumption by deer in a deciduous forest of Southern Poland. Acta theriol., 17: 187-202.

7. Bobek B., Borowski S. \& Dzięciolowski R., 1975: Browse supply in various forest ecosystems. Pol. Ecol. Stud. 1: 17-32.

8. Borowski St. \& Dzięciołowski R., 1980: Browse supply in lowland forests of eastern Poland. Holarctic ecology, 3: 203-213.

9. Bourliere F., 1965: Densities and biomass of some ungulate populations in eastern Congo and Uganda with notes on populations structure and lion ungulate ratios. Zool. Afr., 1: 199-207.

10. Bourliere F., 1975: Mammals, small and large: the ecological implications of size. [In: "Small mammals: their productivity and population dynamios", Eds. Golley F. B., Petrusewicz K. \& Ryszkowski L.]. Cambridge Univ. Press.: 1-8 London.

11. Buechner H. K. \& Golley F. B., 1967: Preliminary estimation of energy flow in Ugand Kob. [In: "Secondary productivity of terrestrial ecosystems", Ed. K. Petrusewicz]. Państw. Wyd. Nauk.: 243-256. Warszawa.

12. Chernov Y. I., Khodashova K. S. \& Zlotin R. I., 1967: (Biomass of terrestrial animals and some regularities in its zonal distribution.) (In Russian), Zur. obšč. Biol., 28: 188-197. 
13. Chew R. M. \& Chew A. E., 1970: Energy relationships of the mammals of a desert shrub (Larrea tridentata) community. Eool. Monogr., 40: 1-20.

14. Clements F. E. \& Shelford V. E., 1939: Bioecology. J. Wiley.: 1-425. New York.

15. Cook C. W., 1971: Why not say it like it is. J. Range Manage., 24: 320-321.

16. Dawson T. J., 1973: Primitive mammals. [In: "Comparative physiology of temperature regulation", Ed. G. Whittow]. Academic Press. Vol. 3: 1-46. New York.

17. Deans R. J., Teague C. M., Signell L. G., John B. M. \& Knickerbocker M. E., 1968: Live stock and range improvement in Masailand. US Dept. Agricul.: $1-156$. Washington.

18. Dinesman L. G., 1961: Vlijanie dikih mlekopitajuščih na formirovanie drevostoev. Izd. Akademii Nauk SSSR: 1-165. Moskva.

19. Dobrinsky L. N., 1975: Optimum density and optimum structure of animal populations. [In: "Resources of the biosphere", Eds. Rodin L. E. \& Smirnov N. N.]. Nauka.: 199-217. Leningrad.

20. Fenchel T., 1974: Intrinsic rate of natural increase, the relationship with body size. Oecologia, 14: $317-326$.

21. Fleming T. H., 1973: Numbers of mammal species in North and Central American forest communities. Ecology, 54: 555-563.

22. Fleming T. H., 1975: The role of small mammals in tropical ecosystems. [In: "Small mammals: their productivity and population dynamics", Eds. F. B. Golley, K. Petrusewicz, L. Ryszkowski]. Cambridge Univ. Press.: 269-298. London.

23. Floster J. B. \& Coe M. J., 1968: The biomass of game animals in Nairobi National Park. J. Zool., 155: 413-425.

24. French N. R. (Ed.), 1979: Perspectives in grassland ecology. Springer Verlag: 1-204. Berlin.

25. French N, R., Stoddart D. M. \& Bobek B., 1975: Patterns of demography in small mammal populations. [In: "Small mammals: their productivity and population dynamics", Eds. Golley F. B., Petrusewicz K., Ryszkowski L.]. Cambridge Univ. Press.: 73-102. London.

26. French N. R., Grant W. E., Grodziński W. \& Swift D. M., 1976: Small mammal energetics in grassland ecosystems. Ecol. Monogr., 46: 201-220.

27. Gębczyńska Z., 1970: Bioenergetics of a root vole population. Acta theriol., 15: $33-66$.

28. Golley F. B., 1960: Energy dynamics of a food chain of an oldfield community. Ecol. Monogr., 30: 187-206.

29. Golley F. B., 1968: Secondary productivity in terrestrial communities. Ann. Zool., 8: $53-59$.

30. Golley F. B., 1973: Impact of small mammals an primary production. [In: "Ecological energetics of homeotherms", ed. J. A. Gessaman]. Utah State Univ. Press: 142-147. Logan.

31. Golley F. B., Ryszkowski L. \& Sokur J. T., 1975: The role of small mammals in temperate forests, grasslands and cultivated fields. [In: "Small mammals their productivity and population dynamics", Eds. F. B. Golley, K. Petrusewicz, L. Ryszkowski]. Cambridge Univ. Press: 223-241. London.

32. Goszczyński J., Ryszkowski L. \& Truszkowski J., 1976: The role of the European hare in the diet of predators in cultivated field systems. [In: "Ecology and management of European hare populations", Eds, Pielowski Z., Pucek Z.]. Państw. Wyd, Roln, Leśne: 127-133, Warszawa, 
33. Grodziński W., 1971: Energy flow through populations of small mammals in the Alaskan taiga forest. Acta theriol., 16: 231-275.

34. Grodziński W., Bobek B., Drożdż A. \& Górecki A., 1969: Energy flow through small rodent populations in a beech forest. [In: "Energy flow through small mammal populations", Eds. K. Petrusewicz, L. Ryszkowski]. Polish Sci. Publ. 291-298. Warszawa.

35. Hansson L., 1971: Estimates of the productivity of small mammals in a South Swedish spruce plantation. Ann. Zool. Fennici, 8: 118-126.

36. Hull J. L., Raguse C. A. \& Henderson D. W., 1971: Further studies on continuous and rotational grazing of irrigated pasture by yearling beef steers and heifers. J. Anim. Sci., 32: $984-988$.

37. Jordan P. A., Botkin D. B. \& Wolfe M. L., 1971: Biomass dynamics in a moose population. Ecology, 52: 147-152.

38. Kolenosky G. B., 1972: Wolf predation on wintering deer in east central Ontario. J. Wildl. Manage., 36: 357-369.

39. Kruuk H., 1970: Interactions between populations of spotted hyaenas (Crocuta crocuta Erxleben) and their prey species. Anim. Pop. Relat. Food Resour., Oxford-Edinburgh: $359-374$.

40. Kruuk H. \& Turner M., 1967: Comparative notes on predation by lion, leopard, cheetah and wild dog in the Serengeti area, East Africa. Mammalia, 31: $1-37$.

41. Lamprey H. F., 1964: Estimation of the large mammal densities, biomass and energy exchange in the Taranjire Game Reserve and the Masai steppe in Tanganika. E. Afr. Wildl. J., 2: 1-46.

42. Mohler L.L., Wampole J. H. \& Fichter J. 1951: Mule deer in Nebraska National Forest. J. Wildl. Manage., 15: 129-157.

43. Nellis C. H., Wetmore S. P. \& Keith L. B., 1972: Lynx-prey interactions in central Alberta. J. Wildl. Manage., 36: 718-722.

44. Odum E. P., Connell C. E. \& Davenport L. B., 1962: Population energy flow of three primary consumer components of old field ecosystems. Ecology, 43. 88-95.

45. Petrides G. A., Golley F. B. \& Brisbin S. L., 1968: Energy flow and secondary productivity. [In: "Productivity of large herbivores", Eds, F. B. Golley, H. K. Buechner]. Blackwell: 9-17. Oxford.

46. Petrides G. A. \& Swank W. G., 1965: Population densities and range carrying capacity for large mammals in Queen Elisabeth National Park, Uganda. Zool. Afr., 1: 209-225.

47. Pielowski Z., Pinowski J., Ryszkowski L. \& Strawiński S., 1974: Tentative appraisal of the role of vertebrates economically important in an agricultural landscape. [In: "Ecological effects of intensive agriculture", Ed. L. Ryszkowski]. Polish Sci. Publ.: 63-83. Warszawa.

48. Poulet A. R., 1972: Recherches ecologiques sur une savane sahelienne du ferlo septentrional, Senegal: les mammiferes. Terre et Vie, 26: 440-472.

49. Reichle D. E., 1971: Energy and nutrient metabolism of soil and litter invertebrates. [In: "Productivity of forest ecosystems", Ed. Duvigneaud P.]. UNESCO: 465-477. Paris.

50. Rodin L. E. (Ed.), 1977: Productivity of vegetation in arid zone of Asia. Nauka: 1-231. Leningrad.

51. Ryszkowski L., 1969: Estimates of consumption of rodent populations in different pine forest ecosystems. [In: "Energy flow through small mammal pop- 
ulations", Eds. K. Petrusewicz, L. Ryszkowski]. Polish Sci. Publ.: 281-289. Warszawa.

52. Ryszkowski L., 1975: Energy and matter economy of ecosystems. [In: "Unifying concepts in ecology", Eds. Dobben W. H., van \& Lowe McConnell R. H.]. Junik: 109-126. Haga.

53. Ryszkowski L., 1979: Consumers. [In: "Grassland ecosystems of the world", Ed. R. T. Coupland]. Cambridge Univ. Press: 309-318. Cambridge.

54. Ryszkowski L., Goszczyński J. \& Truszkowski J., 1973: Trophic relationships of the common vole in cultivated fields. Acta theriol., 18: 125-165.

55. Satchell J. E., 1971: Feasibility study of an energy budget for Meathop Wood. [In: "Productivity of forest ecosystems", Ed. P. Duvigneaud]. UNESCO: 619-630. Paris.

56. Schaller G. B., 1972: The endless race of life. Nat. History, 81: $38-43$.

57. Soholt L. F., 1973: Consumption of primary production by a population of Kangaroo rats (Dipodomys merriami) in the Mojave Desert. Ecol. Monogr., 43: $357-376$.

58. Spotila J. R. \& Gates D. M., 1975: Body size, insulation, and optimum body temperatures of homeotherms. [In: "Perspectives of biophysical ecology", Eds. Gates D. M., Schmerl R. B.]. Springer Verlag: 291-311. New York.

59. Trojan P., 1969/70: Energy flow though a population of Microtus arvalis in an agrocenosis during a period of mass occurrence. [In: "Energy flow through small mammal populations", Eds. K. Petrusewicz, L. Ryszkowski]. Polish Sci. Publ.: 267-276. Warszawa.

60. Turček F. J., 1978: On the vertebrate secondary production of forests. [In: "Productivity of forest ecosystems", Ed. P. Duvigneaud]. UNESCO: 379-385 Paris.

61. Wiegert R. G. \& Evans F. C., 1967: Investigation of secondary productivity in grassland. [In: "Secondary productivity of terrestrial ecosystems", Ed. K. Petrusewicz]. Państw. Wyd. Nauk.: 499-518. Warszawa.

62. Zlotin R. I., 1975: Žizn v vysokogoryah. Mysl: 1-238. Moskva.

63. Zlotin R. I. \& Khodashova K. S., 1974: Rol' životnyh $v$ biologičeskom krugovorote lesostepnyh ekosistem. Nauka: 1-199. Moskva.

Accepted, July 16, 1981.

Lech RYSZKOWSKI i Norman R. FRENCH

ODDZIAEYWANIA TROFICZNE SSAKOW W EKOSYSTEMACH LĄDOWYCH

Streszczenie

Masa ciała ssaków wykazuje dużą zmienność. Najmniejszy ssak lądowy waży około 2 g a największy 5 ton. Dużej zmienności podlega zagęszczenie populacji wielu gatunków ssaków. Skutkiem dużych kosztów energetyeznych stałocieplności jak i dużej zmienności zagęszczenia ssaki odgrywają istotną rolę w przeplywie energii w ekosystemie. W wielu ekosystemach trawiastych biomasa calego zespolu ssaków równoważy lub nawet jest większa od biomasy wszystkich żyjących na powierzchni ziemi i w nadiziemnej warstwie roślinności bezkręgowców. W stosunku do całej biomasy zwierząt stwierdzonej w analizowanych ekosystemach ssaki sta- 
nowią ad około 0.1 do $7.7 \%$ (Tabela 1 ). W 24 analizowanych ekosystemach średnia masa całego zespołu ssaków wykazała zmienność od $1.2 \mathrm{mg} \mathrm{s} . \mathrm{m} . / \mathrm{m}^{2}$ do $330 \mathrm{mg}$ s.m./m² (Tabela 2). Srrednio biomasa zespołu ssaków w lesie jest dziesięć razy większa niż na pustyni. W porównaniu od cenionej biomasy ssaków w lasach ich biomasa w ekosystemach trawiastych jest trzy razy mniejsza. Biomasa kopytnych osiagga największe wartości na terenach chronionych, gdzie ograniczona została działalność drapieżników a zasoby pokarmowe są duże (Tabela 4). W niektórych ekosystemach trawiastych biamasa całego zespołu ssaków przewyższa biomasę bezkręgowców epigeionu (Tabela 5).

Tylko mała część dostępnego pokarmu jest zwykle zjadana przez drobne roślinożerne ssaki (Tabela 6). Wyjątek stanowią sytuacje ich masowego pojawu liczebności. Duże kopytne zjadają znacznie większą część dostępnego pokarmu (Tabela 7), diatego ich liczebność może być ograniczona przez zasoby pokarmowe w większym stopniu niż ma to miejsce wśród drobnych ssaków. Wykazano, że drapieżne ssaki (Tabela 8) zajmują pośrednią pozycję pomiędzy drobnymi ssakami a kopytnymi pod względem wykorzystywania przez nie pokarmu. W przypadku trawiastych ekosystemów drobne ssaki zjadają prawie tyle bezkręgowców co pokarmu roślinnego (Tabela 9). Jednak, jak się wydaje, wpływ drobnych ssaków na bezkręgowce jest większy niż na rośliny (Tabela 10). Drobne ssaki zjadają bardzo duży procent nasion (Tabela 11), przez co oddziaływują na skład gatunkowy odrastającej roślinności. Chociaż przeważająca część kansumpcji w ekosystemach trawiastych jest wywołana przez bezkręgowce glebowe, to jednak, gdy rozważać tylko wielkość pokarmu zjadanego przez epigeion, okazuje się, że udział ssaków jest znaczny. Ta charakterystyka wykazuje, że ssaki są ważnym czynnikiem w przepływie energii przez epigeion.

Znaczenie ssaków w przepływie energii w całym ekosystemie jest male w porównaniu do bezkręgowców (Tabela 12). Ich istotna rola w gospodarce ekosystemu polega na regulacyjnym oddziaływaniu na tempo szeregu procesów, takich jak przemieszczanie składników odżywczych roślin, stymulacja tempa rozkładu materii organicznej, uszkadzanie roślin uprawnych oraz rozprzestrzenianie różnych chorób. Oddziaływując na szybkość przebiegu tych procesów, ssaki wywierają pośredni wpływ na produkcję ekosystemu i gospodarkę człowieka. 